\title{
Disturbance of Serum Viscosity in Diabetes Mellitus
}

\author{
Donald E. McMillan \\ From the Diabetes Research Division, Sansum Medical Research Foundation, \\ Santa Barbara, California 93105
}

A в S TRACT The serum viscosity of diabetic patients has been found to be increased. The elevation averaged $8 \%$ above healthy subjects and $6 \%$ above nondiabetic patients. The serum viscosity elevation was greater when diabetic sequelae associated with microangiopathy were present. No relation of serum viscosity to age, sex, obesity, duration of disease, or type of treatment was demonstrated. Serum total protein and glucose levels were found to be correlated with serum viscosity, and increases in their serum concentrations were observed in diabetes. Analysis demonstrated that their elevation did not explain either the viscosity increase or the difference in viscosity between diabetics with and without sequelae.

Intrinsic viscosity, abbreviated [ $\eta$ ], is a concentrationindependent solute property related to molecular shape. $[\eta]$ was found to be $7 \%$ higher in diabetic than in normal serum. The $[\eta]$ difference accounted for at least half of the serum viscosity elevation. The rest of the increase was due to increased serum protein level and increased nonprotein solids, presumably glucose and lipid. Associated with increased $[\eta]$ was a decline in albumin: globulin ratio and elevation of the acute phase reactant proteins, $\alpha_{1}$-acid glycoprotein, $\alpha_{1}$-antitrypsin, haptoglobin, and ceruloplasmin. Studies comparing diabetic and normal serum fractionated by using $21.5 \%$ sodium sulfate showed that changes in $[\eta]$ were attributable to changes in serum protein composition rather than an inherent qualitative disturbance of protein present in one of the fractions.

Since serum viscosity is elevated in early diabetes, it may be a part of the metabolic disturbance of diabetes and could play a role in the development of diabetic microangiopathy.

\section{INTRODUCTION}

Cogan, Merola, and Laibson first published evidence of serum viscosity elevation in diabetes in 1961 (1).

Received for publication 12 February 1973 and in revised form 15 August 1973.
More recently, Skovborg, Nielson, Schlichtkrull, and Ditzel (2), Labib et al. (3), and Hoare, Beckett, and Dormandy (4) have demonstrated whole blood viscosity increase, and Isogai, Ichiba, Iida, Chikatsu, and Abe whole blood and plasma viscosity increase in diabetes (5). Less conclusive studies suggesting blood viscosity disturbance have also been reported $(6,7)$ and studies describing a total lack of change $(8,9)$ or decrease (10) in plasma, serum, and blood viscosity have appeared.

Differing findings in diabetes are matched by disagreement about the relation of viscosity and diabetic sequelae. Serum viscosity elevation was reported to be similar in diabetes with and without retinopathy (1) but blood viscosity, normal in uncomplicated diabetes of short duration (11), was reported to be increased in long-standing diabetes with retinopathy and associated with changes in serum electrophoretic pattern and fibrinogen levels $(2,11)$.

Studies of serum viscosity changes in diabetes reported here demonstrate a well defined increase which is more pronounced when clinically evident microangiopathy is present. Additional analyses suggest that the increased viscosity is due to specific changes in serum composition.

\section{METHODS}

The study was done in three parts-individual serum viscosity measurements, determination of intrinsic viscosity $([\eta])^{1}$ of large serum pools, and determination of $[\eta]$ of fractions prepared using sodium sulfate on smaller serum pools.

Subject material. Serum for individual viscometry was obtained from 30 healthy subjects, 45 nondiabetic patients, and 45 diabetic patients after overnight fasting. An effort was made to match diabetic and nondiabetic subjects for age and sex. Replicate studies at least 1 wk apart were done on five healthy subjects and 19 diabetic patients. Healthy subjects had no family history of diabetes, were less than $20 \%$ above ideal body weight (12), and had no medical complaints. Nondiabetic patients had normal glucose tolerance during an evaluation for medical com-

${ }^{1}$ Abbreviation used in this paper: [ $\eta$ ], intrinsic viscosity. 
plaints. Glucose tolerance was considered normal if plasma glucose values were all below the following levels: fasting, $115 ; 1 \mathrm{~h}, 175 ; 2 \mathrm{~h}, 125 ; 3 \mathrm{~h}, 125 \mathrm{mg} / \mathrm{dl}$. The nondiabetic patients received a wide-ranging array of diagnoses. Classified by system, there were 17 proctologic, 12 gastrointestinal, 11 dermatologic, 11 orthopedic, 11 cardiopulmonary, nine eye-ear-nose-throat, seven urologic, seven gynecologic, and six psychiatric diagnoses. Inflammatory disease of the urinary tract, bronchial tree, or skin was present in 16 subjects and peptic ulcer disease in four subjects. Malignancy was found in three subjects, two cutaneous and one colon carcinoma with extension. A family history of diabetes was given by 20 nondiabetic patients. Diabetic patients were also ambulatory, 36 had previously diagnosed diabetes and nine had just undergone glucose tolerance tests which were abnormal by the criteria of Wilkerson (13). All established diabetics had received insulin, sulfonylureas, or biguanides, while none of the abnormal glucose tolerance subjects had received any treatment. All diabetic subjects were examined for evidence of microangiopathic sequelae. Established diabetics had ophthalmoscopic examinations, were studied for age-adjusted vibration sense loss of the index finger and great toe by using a biothesiometer (14), and had quantitative determinations of protein on 24-h urine specimens. Clearly recognizable microaneurysms, usually with exudates, were considered evidence of retinopathy. Diminution of vibration sense disproportionate to age was considered evidence of neutropathy. Proteinuria in excess of $300 \mathrm{mg}$ daily was considered evidence of nephropathy.

The two pairs of serum pools used in the second part of the study were composed of equal amounts of previously frozen serum from overt diabetic or healthy subjects matched for age and sex. Some findings on the first pair of pools have already been reported (15). The second matched pools were from eight male and 12 female subjects; mean ages were diabetic, $41.1 \mathrm{yr}$; control, $41.7 \mathrm{yr}$.

The studies of part three were carried out on smaller pools of fresh serum from overt diabetic and healthy subjects. Both control pools and the first diabetic pool were from four subjects each, the second diabetic pool was from six subjects.

$V$ iscosity studies. Studies of viscosity of individual sera (part one) were done using a Wells-Brookfield model LVT cone-plate viscometer (Brookfield Engineering Laboratories, Inc., Stoughton, Mass.) (16). Cone-plate viscometry was used because it is rapid, gives measurement directly in viscosity units (centipoise), and allows determination at different shear rates. Data were obtained at $37.0^{\circ} \mathrm{C}$, and shear rate, $230 \mathrm{~s}^{-1}$ values were used in these analyses after 12 diabetic and 11 control sera were found to have the same viscosity at shear rates from 23 to 230 $\mathrm{s}^{-1}$. Viscometer precision was best at the highest available shear rate, $230 \mathrm{~s}^{-1}$. Cannon calibration oil (2.35 $\mathrm{cP}$ at $37.0^{\circ} \mathrm{C}$ ) was used to calibrate the instrument. The sample volume required to give suitable readings in the viscometer used for these studies was $1.25 \mathrm{ml}$. Serum viscosity readings were repeated each minute until stable values were obtained; this usually required $5-10 \mathrm{~min}$ at $37.0^{\circ} \mathrm{C}$. The solvent used in calibration was $0.15 \mathrm{M}$ saline containing $6 \times 10^{-4} \mathrm{M}$ sodium dodecyl sulfate.

Pooled serum studies (parts two and three) were done with a Cannon-Ubbelohde semi-micro viscometer (Cannon Instrument Co., State College, Pa.) at $37.0^{\circ} \mathrm{C}$. The first pair of dilution studies (Diabetic and Control Pool no. 1) were done with a size 75 viscometer (solvent time, $90.0 \mathrm{~s}$ ); all other analyses used size 50 viscometers (solvent times, 182.27-210.89 s). Operation was essentially that advocated by Kragh (17), including filtration of all samples through fine sintered glass. Two patterns of dilution were used. In the size 75 viscometer studies $1.0 \mathrm{ml}$ of serum was placed in the viscometer initially with subsequent additions of $0.2,0.3,0.5$, and $0.5 \mathrm{ml}$ of $0.15 \mathrm{M}$ sodium chloride solution (saline) producing solutions $5 / 6,2 / 3,1 / 2$, and $2 / 5$ the initial concentration. In the size 50 viscometer studies $2.0 \mathrm{ml}$ of serum was used initially and $0.5,0.5,1.0$, and 1.0 $\mathrm{ml}$ of saline were added sequentially to produce $4 / 5,2 / 3$, $1 / 2$, and $2 / 5$ the initial concentration.

Smaller serum pools were studied (part three) after salt fractionation was carried out by adding $150 \mathrm{ml}$ of $23 \%$ sodium sulfate to $10 \mathrm{ml}$ of pooled serum. Whole serum, supernate, and precipitate, the last redissolved by the addition of $15 \mathrm{ml}$ of water, were then dialyzed against $0.15 \mathrm{M}$ saline and the salt fractions concentrated to $5 \mathrm{ml}$ or less with a Zeineh Microconcentrator (Biomed Instruments, Inc., Chicago, Ill.).

Other determinations. Serum protein concentrations were measured by using the biuret reagent of Gornall, Bardawill, and David (18). Serum glucose was determined by the Hoffman ferricyanide technique in the glucose tolerance studies and by the phenol-methyl salicylate- $\mathrm{H}_{2} \mathrm{SO}_{4}$ (Hycel) technique in the established diabetics. The serum total solids content of capillary viscometry samples was determined by placing duplicate $1.0-\mathrm{ml}$ aliquots in tared weighing bottles and drying them in vacuo over phosphorus pentoxide overnight and then for $2 \mathrm{~h}$ in vacuo at $106.5 \pm 1.5^{\circ} \mathrm{C}$ before weighing. All values were corrected for sodium chloride content by subtracting $0.88 \mathrm{~g} / \mathrm{dl}$.

Radial immunodiffusion was used for measurements of individual serum proteins. Both plates and standards were obtained from Behring Diagnostics, Inc., Woodbury, N. Y. The same plate was used for duplicate studies of all four pools. The serum standard was used at three concentrations selected so that the sample concentrations fell within their range. The diameter (D) of all rings was measured, and sample concentration was determined graphically from a least squares plot of $\mathrm{D}^{2}$ for the three concentrations of the serum standard.

The electrophoretic analysis technique was designed to correct for increased stainability of albumin. Approximately $2 \mu 1$ of serum was applied in a $1-\mathrm{cm}$ band to $2.5-$ $\mathrm{cm}$-wide cellulose acetate strips (Oxoid), and the proteins were migrated $60 \mathrm{~min}$ at $200 \mathrm{~V}$ in a Colab Unitized ${ }^{\text {TM }}$ electrophoresis tank (Colab Laboratories, Inc., Chicago Heights, Ill.). The wet strips were then stained by floating them on a $0.2 \%$ Ponceau $\mathrm{S}$ solution containing $3 \%$ trichloracetic acid, and destained by rinsing in $5 \%$ acetic acid. The uncleared globulin areas were scanned on a Photovolt Densicord scanner (Photovolt Corp., New York), using logarithmic compensation and a 595-nm filter. The albumin: globulin ratio was measured by eluting dye from appropriate strip segments. Cellulose acetate pieces of similar size from the same strip were also eluted as blanks. Elution with $3 \mathrm{ml} 0.1 \%$ sodium hydroxide was followed by addition of 2 drops of glacial acetic acid to restore normal color. The absorbance at $525 \mathrm{~nm}$ and $610 \mathrm{~nm}$ was then measured on a Hitachi 139 spectrophotometer; the latter wavelength reading was used to correct for lightscattering elements eluted from strips.

Calculation of data. Serum viscosity values determined by cone-plate viscometry are reported directly in centipoise at $230 \mathrm{~s}^{-1}$. Capillary viscometry flow times were 
TABLE I

Serum Viscosity Levels

\begin{tabular}{lccc}
\hline & $\begin{array}{c}\text { Number } \\
\text { of } \\
\text { subjects }\end{array}$ & Mean \pm SD & Test of difference \\
\hline Healthy subjects & 30 & $c P^{*}$ & \\
Nondiabetic patients & 45 & $1.155 \pm 0.065$ & $t=1.3$ \\
Diabetic patients & 45 & $1.250 \pm 0.079$ & $t=5.7, P<0.001$ \\
Diabetics, no sequelae & 28 & $1.231 \pm 0.079$ & $t=2.6, P<0.02$ \\
Diabetics, sequelae & 17 & $1.282 \pm 0.070$ & \\
Duration less than 5 yr & 22 & $1.243 \pm 0.096$ & $t=0.8$ \\
Duration 5 yr or more & 23 & $1.258 \pm 0.057$ & $t=0.9$ \\
Diabetics on insulin & 16 & $1.265 \pm 0.085$ & \\
Diabetics on oral agents & 20 & $1.246 \pm 0.071$ & \\
\hline
\end{tabular}

* Viscosity is reported in centipoise $\left(0.01 \mathrm{dyn} \cdot \mathrm{s} / \mathrm{cm}^{2}\right)$ at $37.0^{\circ} \mathrm{C}$. The viscosity of water is $0.69 \mathrm{cP}$ at that temperature. Values of $t$ not specifically marked are not statistically significant.

initially expressed as relative viscosity, $\eta_{\mathrm{rel}}$ (19), by using the following formula:

$$
\eta_{\mathrm{rel}}=D \times T_{\text {sample }} / T_{\text {solvent }}
$$

where $D$ is a factor to correct for increased sample density and $T_{\text {sample }}$ and $T_{\text {solvent }}$ the observed mean flow times for the sample and $0.15 \mathrm{M}$ saline. The solvent time was adjusted to $47 \mathrm{dyn} / \mathrm{cm}$ surface tension." The density factor was calculated by using the following formula:

$$
D=1+0.29 \mathrm{dp} /(1+0.71 p)
$$

where $d$ is the dilution, unity for the undiluted sample, and $p$ is the protein concentration in $\mathrm{g} / \mathrm{ml}$. While using a partial specific volume reasonable for serum, the formula is essentially empiric; it was used because of its close relation to measured plasma densities (20). [ $\eta$ ] was calculated by using Kraemer's equation (19) as applied by Oncley, Scatchard, and Brown (21). Each $\eta_{\mathrm{re} 1}$ was converted to inherent viscosity, $\{\eta\}$ :

$$
\{\eta\}=\left(\log _{\bullet} \eta_{\mathrm{rel}}\right) / C
$$

where $C$ is the total dissolved solids concentration in $\mathrm{g} / \mathrm{ml}$. The linear regression of $\{\eta\}$ with concentration was extended to zero concentration by the least squares technique (22) with concentration considered the independent variable.

Kinetic energy correction was omitted after the effect of the correction formula of Cannon, Manning, and Bell (23) on intrinsic viscosity determination was found to be less than $0.1 \%$ with solvent time as short as $90.0 \mathrm{~s}$.

Capillary viscometer studies were compared to cone-plate data by multiplying relative viscosity by the viscosity of $0.15 \mathrm{M}$ sodium chloride at $37.0^{\circ} \mathrm{C}, 0.7036 \mathrm{cP}$ (24).

Electrophoresis calculations began by determining the albumin: globulin ratio. The blank eluate absorbances were subtracted from albumin and total globulin absorbances at both 525 and $610 \mathrm{~nm}$. Next, light-scattering correction was

${ }^{2}$ MoMillan, D. E. Capillary viscometry-Surface tension effects. Submitted for publication. made by using the formula,

$$
A_{\text {corr }}=\frac{0.657 A_{525}-A_{610}}{0.652}
$$

where 0.657 and 0.652 are constants reflecting the ratio of dye absorbance and light-scattering at 525 and $610 \mathrm{~nm}$. The corrected albumin absorbance was then multiplied by 0.62 to adjust for greater intensity of albumin staining. The factor 0.62 was found by comparing albumin and globulin Ponceau $S$ content in 24 pairs of strips with protein content determined by direct measurement of eluates of freshly separated fractions using the method of Lowry, Rosebrough, Farr, and Randall (25). Then the adjusted albumin absorbance and the globulin absorbance were divided by their sum to determine the percentage of albumin and globulin present. The percentage in the $\alpha_{1-}, \alpha_{s-}$, $\beta$-, and $\gamma$-globulin fractions was calcuiated by multiplying the globulin percentage by the proportion of each fraction in the total globulin of the scanned strip.

Statistical methods. Individual serum viscosity data were studied by using analysis of variance of four groups after replicate observations were averaged. The four groups were healthy subjects, nondiabetic patients, diabetics without sequelae, and diabetics with one or more of the three evaluated types of diabetic sequelae. The within groups mean square was used as the estimated variance in further $t$ tests. Nested analysis of variance was used to derive the replicate observation (within subject) coefficient of variation; linear regression, correlation, and multiple covariance also followed standard techniques (22).

\section{RESULTS}

Serum viscosity values, expressed as mean and standard deviation, are presented in Table I. The diabetic patients showed a significant elevation compared to both the healthy subjects and nondiabetic patients. The latter two group means did not differ significantly. When the 
TABLE II

Effects of Age, Sex, and Obesity on Serum Viscosity

\begin{tabular}{|c|c|c|c|c|c|}
\hline \multirow{4}{*}{$\begin{array}{l}\text { Age } \\
\text { Healthy Subjects } \\
\text { Nondiabetic Patients } \\
\text { Diabetic Patients }\end{array}$} & \multicolumn{2}{|c|}{ Age less than 50} & \multicolumn{2}{|c|}{ Age $50-59$} & \multirow{2}{*}{$\frac{\text { Age }}{1.178}$} \\
\hline & $1.146 \pm 0.071$ & $1[22]$ & $1.182 \pm$ & $44 \quad[5]$ & \\
\hline & $1.170 \pm 0.051$ & $1[20]$ & $1.192 \pm$ & $41[13]$ & $1.165=$ \\
\hline & $1.257 \pm 0.088$ & $3[15]$ & $1.247 \pm$ & $3[17]$ & $1.245=$ \\
\hline & & \multicolumn{2}{|c|}{ Male } & \multicolumn{2}{|c|}{ Female } \\
\hline Healthy Subjects & & \multicolumn{2}{|c|}{$1.180 \pm 0.038$} & \multicolumn{2}{|c|}{$1.148 \pm 0.070\lceil 23\rceil$} \\
\hline Nondiabetic Patien & & \multicolumn{2}{|c|}{$1.173 \pm 0.039[19]$} & \multicolumn{2}{|c|}{$1.177 \pm 0.053[26]$} \\
\hline Diabetic Patients & & \multicolumn{2}{|c|}{$1.245 \pm 0.076[19]$} & \multicolumn{2}{|c|}{$1.254 \pm 0.082[26]$} \\
\hline & & \multicolumn{2}{|c|}{ Less than $20 \%$} & \multicolumn{2}{|c|}{$\begin{array}{c}\text { More than } 20 \% \text { above } \\
\text { ideal weight }\end{array}$} \\
\hline $\begin{array}{l}\text { Obesity } \\
\text { Healthy Subiects }\end{array}$ & & & \multicolumn{2}{|c|}{ None } \\
\hline Nondiabetic Patients & & \multicolumn{2}{|c|}{$\begin{array}{l}1.153 \pm 0.003[30] \\
1.165 \pm 0.039[24]\end{array}$} & \multicolumn{2}{|c|}{$1.187 \pm 0.052[21]$} \\
\hline Diabetic Patients & & \multicolumn{2}{|c|}{$1.244 \pm 0.068[13]$} & \multicolumn{2}{|c|}{$1.253 \pm 0.084[32]$} \\
\hline
\end{tabular}

Values are in centipoise at $37.0^{\circ} \mathrm{C}$, given as mean $\pm \mathrm{SD}$. The number of subjects in each group is shown in brackets. Age, sex, and obesity values were not statistically significantly different within groups, but significant differences remained when diabetic and nondiabetic patients were compared in each component

diabetic patients were separated into those with and those without microangiopathic sequelae the group with sequelae had a higher mean value. The means differed by $4 \%$. When the viscosity values were segregated by specific sequelae, the following mean values were found: retinopathy $1.280 \mathrm{cP}$ [10], neuropathy $1.277 \mathrm{cP}[10]$, and nephropathy $1.278 \mathrm{cP}$ [9]. The excess of number of observations (in brackets) over total diabetics with sequelae is due to the presence of multiple sequelae in nine diabetics. Two other comparisons in the diabetic group based on duration and type of treatment showed no difference despite the fact that more patients with microangiopathic sequelae had long duration insulinrequiring diabetes. The short duration group was made somewhat lower by the presence of nine untreated, newly diagnosed, mild diabetics whose serum viscosity was $1.233 \pm 0.089 \mathrm{cP}$.

The effects of age, sex, and obesity on serum viscosity in the three groups are shown in Table II. Mean age values were $39 \mathrm{yr}$ for the healthy control, $50 \mathrm{yr}$ for the patient control, and $52 \mathrm{yr}$ for the diabetic group. As suggested by Table II no correlation of serum viscosity with age was found, nor was a serum viscosity difference based on sex found. A nonsignificant tendency for obesity to be associated with higher serum viscosity clearly did not account for the elevation of serum viscosity in our rather obese diabetic population.

Two or more viscosity studies were made on five healthy subjects and 19 diabetic patients. Replicate variation may be compared to group variation to assess the accuracy of a single observation. The healthy sub- ject replicate coefficient of variation $[n=10]$ of $2.5 \%$ was smaller than the group variation of $5.6 \%$, but the diabetic patient individual variation $[n=48]$ of $4.6 \%$ was nearly as large as the $6.3 \%$ group variation. The value of more than one study per subject was illustrated even more clearly when the 19 diabetic patients with replicate analyses were divided into nine without and ten with sequelae. A $t$ test performed directly on their mean values showed statistical significance as high as for the entire group, $t=2.8, P<0.02$.

Adding sugar to any aqueous solution will raise its viscosity so that elevated levels of glucose could play a role in increasing serum viscosity in diabetes. Total serum protein levels also fluctuate and might affect serum viscosity. Serum glucose was measured in 43 diabetic and 45 nondiabetic patients, and total serum protein in 42 diabetics, 45 nondiabetic patients, and 24 healthy subjects. Both glucose and protein were measured in 40 diabetics. The serum viscosity and fasting glucose levels were positively correlated in the diabetics $(r=+0.30, P<0.05)$ but not in nondiabetic patients $(r=+0.01)$. Serum viscosity and total protein were positively correlated in diabetic $(r=+0.36$, $P<0.05)$ and nondiabetic patients $(r=+0.50, P<$ $0.001)$. The healthy control protein-viscosity correlation did not achieve statistical significance $(r=+$ 0.27 ).

The effect of increased serum glucose and protein levels on serum viscosity has been assessed by using multiple analysis of covariance (Table III). Mean serum protein levels were considerably higher in the 
TABLE III

Effect of Protein and Glucose Levels on Serum Viscosity in Diabetes

\begin{tabular}{|c|c|c|c|c|c|c|}
\hline & $\begin{array}{c}\text { Number } \\
\text { of } \\
\text { subjects }\end{array}$ & $\begin{array}{l}\text { Mean serum } \\
\text { protein level }\end{array}$ & Glucose level & $\begin{array}{l}\text { Mean serum } \\
\text { viscosity }\end{array}$ & $\begin{array}{l}\text { Adjusted } \\
\text { mean serum } \\
\text { viscosity* }\end{array}$ & Test of difference \\
\hline & & $g / d l \ddagger$ & $m g / d l$ & $c P$ & $c P$ & \multirow{4}{*}{$\begin{array}{c}t=0.4 \\
t=5.3, P<0.001\end{array}$} \\
\hline Healthy Subjects & 24 & $7.11 \pm 0.07$ & $91 \pm 1$ & $1.170 \pm 0.010$ & 1.170 & \\
\hline Nondiabetic Patients & 45 & $7.37 \pm 0.08$ & $91 \pm 1$ & $1.175 \pm 0.007$ & 1.163 & \\
\hline Diabetic Patients & 40 & $7.53 \pm 0.10$ & $180 \pm 13$ & $1.256 \pm 0.012$ & 1.236 & \\
\hline Diabetics, no sequelae & 24 & $7.56 \pm 0.11$ & $168 \pm 16$ & $1.237 \pm 0.017$ & 1.216 & \multirow{2}{*}{$t=2.5, P<0.02$} \\
\hline Diabetics, sequelae & 16 & $7.49 \pm 0.21$ & $199 \pm 21$ & $1.284 \pm 0.015$ & 1.266 & \\
\hline
\end{tabular}

* Adjustments of serum viscosity mean values are based on multiple analysis of covariance (22) of data from 40 diabetic and 45 nondiabetic patients on whose serum samples glucose, total protein, and viscosity were measured. Mean serum viscosity was adjusted to the mean healthy control protein and glucose levels shown above and then statistical comparisons were performed. The healthy control mean $\pm \mathrm{SE}$ glucose values were not measured but assumed to be the same as the nondiabetic patient mean \pm SE fasting values.

$\ddagger$ Mean \pm SEM.

nondiabetic and diabetic patients than in healthy subjects. The adjusted serum viscosity levels were very similar in the two nondiabetic groups. The adjusted diabetic mean remained $6 \%$ above the nondiabetic means, and when diabetics with sequelae are compared to those without, the difference remained significant.

Dilution studies were performed on two pools of diabetic serum and two control serum pools. [ $\eta]$ values $(\mathrm{ml} / \mathrm{g})$ were found to be 5.31 and 5.51 for the diabetic, and 5.02 and 5.08 for the control pools (Fig. 1). In order to compare the dilution study capillary viscometry data with the cone-plate viscometer data, the relative viscosities of the undiluted serum were averaged and converted to centipoise. For the diabetic

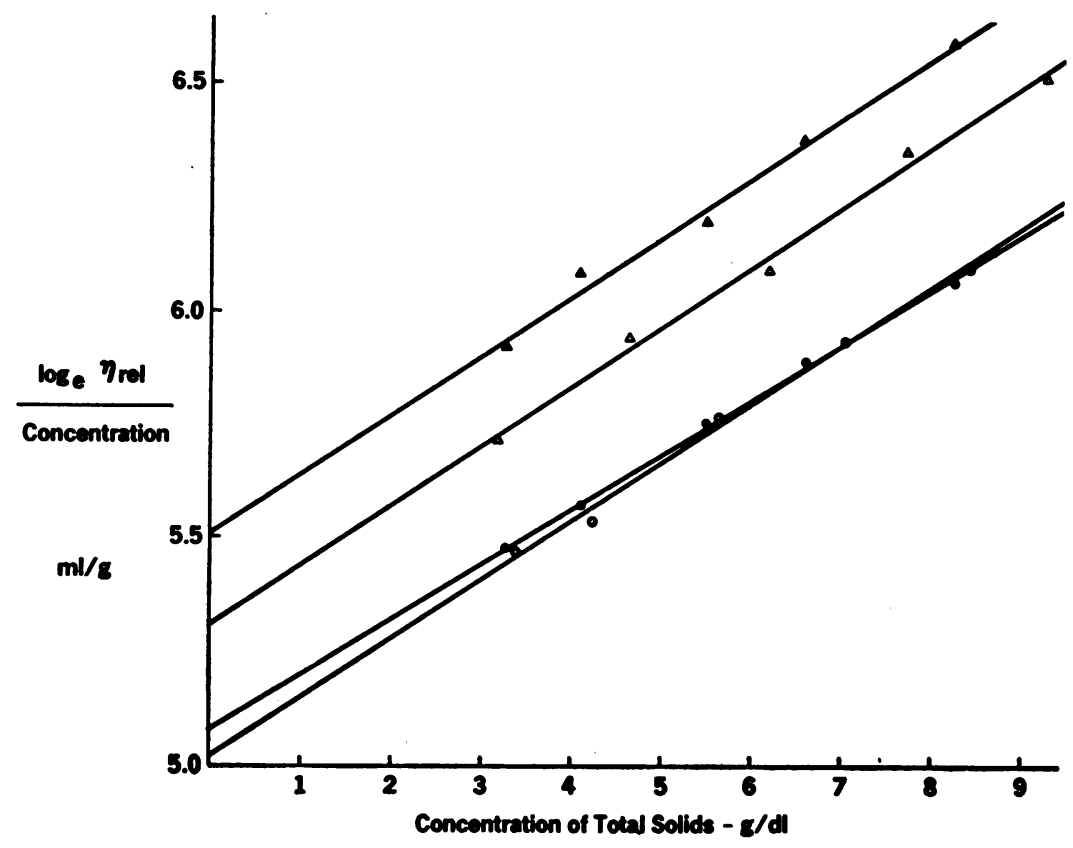

FIGURE 1 The least squares regression lines of points at five concentration levels of the natural logarithm of relative viscosity divided by concentration are plotted. Concentration is that of total serum solids including protein, lipid, and glucose. The zero concentration intercept is referred to as the intrinsic viscosity or [ $\eta]$ (for definitions of terms, see Calculation of data section, Methods). Diabetic pools are represented by triangles, control by circles; open symbols are used for the first pair of studies, solid for the second. 
TABLE IV

Serum Protein Composition Analyses (Mean of Pools 1 and 2)

\begin{tabular}{|c|c|c|c|}
\hline & Diabetic & Control & $\begin{array}{l}\text { Diabetic } \\
\text { to } \\
\text { control } \\
\text { ratio }\end{array}$ \\
\hline Major components & $8 / d l$ & $g / d l$ & \\
\hline $\begin{array}{l}\text { Total Serum Solids } \\
\text { Total Serum Protein }\end{array}$ & $\begin{array}{l}8.76 \\
7.49\end{array}$ & $\begin{array}{l}8.35 \\
7.22\end{array}$ & $\begin{array}{l}1.05 \\
1.04\end{array}$ \\
\hline Electrophoretic analyses & $\%$ & $\%$ & \\
\hline $\begin{array}{l}\text { Albumin } \\
\alpha_{1} \text {-globulin } \\
\alpha_{2} \text {-globulin } \\
\beta \text {-globulin } \\
\gamma \text {-globulin }\end{array}$ & $\begin{array}{r}55.5 \\
3.9 \\
12.8 \\
12.8 \\
16.0\end{array}$ & $\begin{array}{r}60.4 \\
3.4 \\
11.1 \\
10.3 \\
14.8\end{array}$ & $\begin{array}{l}0.92 \\
1.15 \\
1.15 \\
1.15 \\
1.08\end{array}$ \\
\hline Individual protein levels & $m g / d l$ & $m g / d l$ & \\
\hline 1. $\alpha_{1}$-acid glycoprotein & 81 & 55 & 1.47 \\
\hline 2. $\alpha_{1}$-antitrypsin & 296 & 231 & 1.28 \\
\hline 3. Haptoglobin $\left(\alpha_{2}\right)$ & 262 & 172 & 1.52 \\
\hline 4. $\alpha_{2}$-macroglobulin & 231 & 235 & 0.98 \\
\hline 5. Ba- $\alpha_{2}$-glycoprotein & 55 & 53 & 1.04 \\
\hline 6. Ceruloplasmin $\left(\alpha_{2}\right)$ & 56 & 44 & 1.27 \\
\hline 7. Transferrin $(\beta)$ & 232 & 224 & 1.04 \\
\hline 8. Hemopexin $(\beta)$ & 114 & 104 & 1.10 \\
\hline 9. $\beta_{1} \mathrm{C}$-globulin & 129 & 110 & 1.17 \\
\hline 10. $\beta_{2}$-glycoprotein I & 26 & 24 & 1.08 \\
\hline 11. $\operatorname{Ig} A(\beta-\gamma)$ & 188 & 159 & 1.18 \\
\hline 12. $\operatorname{IgM}(\beta-\gamma)$ & 120 & 106 & 1.13 \\
\hline 13. $\operatorname{IgG}(\gamma)$ & 1,047 & 1,011 & 1.04 \\
\hline
\end{tabular}

pools, the value was $1.250 \mathrm{cP}$ and the control pools $1.169 \mathrm{cP}$. These values are quite close to those in Tables I and III.

The serum protein composition of the two diabetic and two control pools was studied in detail. Mean values are given in Table IV. Electrophoretic analyses demonstrated a decrease in albumin:globulin ratio. Levels of individual globulins are also listed. The ratio of diabetic to normal level is given to help assess the degree of elevation.

Four smaller serum pools were studied by using salt fractionation to determine whether differences between diabetic and control fractions could be detected. Dialyzed serum and two separated fractions were analyzed. Dialyzed diabetic serum $[\eta]$ was higher than control serum $[\eta]$ (Table V), as was that of the supernatant fraction. Infranatant fraction values were quite similar. Electrophoretic studies demonstrated differing albumin percentages in the diabetic and control fractions. Simultaneous equations were used to calculate albumin and globulin $[\eta]$ values from the original observations; the derived $[\eta]$ values, also shown in Table V, were similar in the diabetic and control pools.

\section{DISCUSSION}

The major finding of this study was an elevation of serum viscosity in diabetes related in degree to the presence or absence of clinically recognizable diabetic microangiopathy (Table I). No effect of duration of diabetes on serum viscosity was observed despite the relation of both to diabetic microangiopathy. Insulin requirement had little or no relation to increased serum viscosity. Age, sex, and the presence of obesity were demonstrated to be unrelated to the observed changes (Table III). The serum viscosity level in diabetes was found to be correlated with serum protein and glucose levels but increased glucose and protein levels did not account for either the viscosity elevation in diabetes or the difference in serum viscosity between diabetics with or without microangiopathy (Table III). Increased serum viscosity was directly related both to the diabetic state and to diabetic microangiopathy.

TABLE V

Salt Fractionation Studies

\begin{tabular}{|c|c|c|c|c|c|c|c|c|}
\hline & \multicolumn{3}{|c|}{ Observed $[\eta]$} & \multicolumn{3}{|c|}{ Albumin Content } & \multicolumn{2}{|c|}{ Calculated $[\eta]$} \\
\hline & Serum & Supernate & Infranate & Serum & Supernate & Infranate & Albumin & Globulin \\
\hline & \multicolumn{3}{|c|}{$\mathrm{ml} / \mathrm{g}$} & \multicolumn{3}{|c|}{$\%$} & \multicolumn{2}{|c|}{$m l / g$} \\
\hline Diabetic & 5.49 & 4.58 & 7.03 & 52.7 & 76.9 & 7.8 & 3.76 & 7.31 \\
\hline Control & 5.14 & 4.37 & , 7.08 & 61.1 & 83.0 & 10.7 & 3.73 & 7.48 \\
\hline
\end{tabular}

Values are the mean from studies of two separate small serum pools; $21.5 \%$ sodium sulfate and centrifugation were used to separate serum into supernatant and infranatant fractions. The separated fractions were freed of excess salt by dialysis, and their intrinsic viscosity $[\eta]$ determined. Electrophoretic studies measured the albumin and globulin percentages in each fraction, and albumin and globulin [ $\eta]$ values were calculated using simultaneous equations, assuming the globulin $[\eta]$ to be the same in supernatant and infranatant fractions. 
Previously published studies have produced a less distinct picture. The elevation observed in this study is comparable to the increased serum viscosity observed by Cogan et al. (1) and the plasma viscosity increase reported by Isogai et al. (5). Other studies have not demonstrated as large an increase (8-11). A possible explanation for this disagreement may be developed by integrating observations from this study with three previously reported phenomena. Serum viscosity has been shown to be correlated with serum protein level. An individual's serum protein level is affected by his recent posture and physical activity (26). The increased protein level is the result of loss of plasma volume during standing and exercise. The plasma volume decreases more rapidly in diabetes in these circumstances (9). In contrast to the elevated serum protein levels found in ambulatory outpatient diabetics in this study (Table III), hospitalized diabetics have depressed serum protein levels (27). The control subjects and diabetic and nondiabetic patients in this study came from their residence to the laboratory, usually by automobile. They had to walk from their cars to the laboratory and often sat several minutes before venesection. The recent activity of subjects studied has not been specified in past reports, but difference in recent physical activity forms a probable basis for much of the difference in observed viscosity levels.

Cogan et al. (1) failed to demonstrate an elevation of serum viscosity in diabetic retinopathy. While a difference in serum protein level caused by differing activity patterns might form a partial explanation of this failure, two additional considerations are probably important. First, there is a high day-to-day individual variation in serum viscosity, especially in diabetics. Measurement of serum viscosity on two or more occasions was important in demonstrating the distinction between diabetics with microangiopathic sequelae and those without. Second, all three types of diabetic sequelae require evaluation. If individuals with diabetic retinopathy are compared with diabetics without eye involvement but who have nerve or kidney damage, it would be difficult to demonstrate a serum viscosity increase.

The demonstration by statistical techniques that increased serum viscosity in diabetes is not due to increased glucose and protein levels (Table III) has been further corroborated by capillary viscometry on pooled diabetic and control serum (Fig. 1). In the latter studies both total serum protein and total serum solids were measured (Table IV). The difference between total serum solids and total protein is due principally to serum glucose and lipids, both of which are elevated in diabetes. If increased total protein, glucose, and lipid levels in diabetic serum cause the increased serum viscosity when diabetic serum is diluted to the same total solids concentration as control serum the viscosity should be the same. Not only is this untrue (Fig. 1), but if one converts the inherent viscosity to serum viscosity in centipoise the proportion of the elevation of serum viscosity due to increased protein and nonprotein solids may be determined. When the diabetic pool content is reduced $0.27 \mathrm{~g} / \mathrm{dl}$ to correct for increased protein content, serum viscosity falls from $1.250 \mathrm{cP}$ to $1.224 \mathrm{cP}$. When the mean diabetic pool content is reduced $0.41 \mathrm{~g} / \mathrm{dl}$ to correct for increased total solids, serum viscosity falls to $1.211 \mathrm{cP}$, compared with the mean control pool serum viscosity of 1.169 cP. Increased protein and nonprotein solids content accounted for less than half of the increased serum viscosity in diabetes. The major factor increasing serum viscosity in diabetes was an elevation of serum [ $\eta]$.

Serum [ $\eta]$ was elevated $7 \%$ in diabetes. Understanding the meaning of this elevation requires a brief review of the concept of $[\eta]$. Dissolving any solid in water will produce a solution higher in viscosity than water alone. The degree of elevation produced per unit solid is a function of the shape in solution of its component molecules. Einstein examined the theoretical basis for the viscosity effect of rigid spheres in an incompressible fluid and proposed the relationship:

$$
k^{*}=k(1+2.5 \phi)
$$

where $k$ and $k^{*}$ are the viscosities of the solvent and solution, respectively, and $\phi$ is the fractional volume occupied by the spheres (28). His analysis has been confirmed experimentally (29). When nonspherical particles are studied the increment is greater than $2.5 \phi$ because the particles rotate during flow producing a higher flow resistance per unit volume. Since the actual volume in solution of a protein molecule is not directly measurable the concept of $[\eta]$ was developed so that the product of $[\eta]$ and protein concentration, $[\eta] C$, could be used in place of $2.5 \phi$ as the viscosity increment. For Einstein's rigid spheres with a density of $1.0 \mathrm{~g} / \mathrm{ml}$ [ $\eta$ ] would be $2.5 \mathrm{ml} / \mathrm{g}$. A substance of higher $[\eta]$ would produce a greater incremental elevation of solution viscosity. In general, a protein's [ $\eta$ ] is related to its molecular shape, more elongated molecules having higher values because their rotation during flow disturbs laminar flow more than the rotation of rounder molecules. Elevation of intrinsic viscosity in diabetes indicates that in diabetes either there is a difference in the shape of serum protein molecules or that increased amounts of higher [ $\eta]$ proteins are present.

Changes in the concentration of several serum proteins accompanied the increased [ $\eta]$ of the diabetic 
pooled serum (Table IV). Albumin levels decreased while several globulins were present in higher concentrations. The four acute phase reactants measured, haptoglobin, $\alpha_{1}$-acid glycoprotein, $\alpha_{1}$-antitrypsin, and ceruloplasmin, were elevated more than $25 \%$ in diabetic serum. These proteins are called "acute phase reactants" because their levels increase after injury, surgery, and other types of stress or illness $(30,31)$. The $[\eta]$ of albumin and three of the acute phase reactants have been measured: albumin, $3.7-4.2 \mathrm{ml} / \mathrm{g}$ $(21,32,33) ; \alpha_{1}$-acid glycoprotein, $6.9 \mathrm{ml} / \mathrm{g}(34) ; \alpha_{1-}$

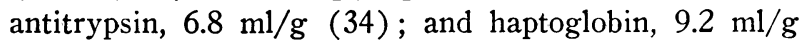
(21). The immune globulins have variable $[\eta]: \operatorname{IgG}$, $5.5-10.2 \mathrm{ml} / \mathrm{g} \mathrm{(35);} \mathrm{and} \mathrm{IgM,} \mathrm{19-28} \mathrm{ml/g} \mathrm{(36).}$ Serum $[\eta]$ averaged $5.05 \mathrm{ml} / \mathrm{g}$ for the two control pools. This value lies between the $[\eta]$ of albumin and the various globulins. A decline in albumin and rise in globulin levels would therefore be expected to produce an increase in serum $[\eta]$. The observed change in serum protein composition in diabetes would be expected to increase serum $[\eta]$.

A direct assessment of possible additional qualitative change of serum proteins in diabetes which might contribute to the $[\eta]$ elevation is shown in Table V. Salt fractionation of serum was combined with mathematical calculations by using electrophoretic analyses of the salt-separated fractions. Neither the $[\eta]$ of albumin nor of total globulin was seriously altered in diabetes. This direct evidence against partial protein denaturation or some other qualitative serum protein change in diabetes indicates that the change in protein composition is entirely responsible for the increased serum $[\eta]$ in diabetes.

The observed increase in serum viscosity in diabetes is considerably less than that known to produce symptoms. In the hyperviscosity syndrome, serum viscosity is typically more than doubled $(35,37)$. Despite this quantitative difference, the hyperviscosity syndrome shares some features with diabetic microangiopathic sequelae. Retinopathy occurs frequently, neurologic abnormalities are seen regularly, and proteinuria is often present (37). While the conditions appear to differ in severity they also differ in rate of development. Changes too mild to produce symptoms might still gradually produce a disturbance of the microcirculation.

If increased serum or plasma viscosity is important in the pathogenesis of diabetic microangiopathy, an additional factor unique to diabetes might be required. Other chronic conditions are associated with changes in both viscosity (5) and serum protein composition (35) similar to those observed in diabetes. Elevated serum $[\eta]$ has been observed in rheumatic fever, tuberculosis, and carcinoma (31). Since serum viscosity elevation in chronic disorders is probably not unique to diabetes, three possible explanations of the relation of increased serum viscosity to diabetic microangiopathy can be entertained. First, elevated serum viscosity may be due to an underlying metabolic disturbance which produces both serum protein changes and diabetic microangiopathy. Second, the duration of blood viscosity increase combined with its degree of elevation might be unique to diabetes so that in other chronic disorders not enough time elapses to produce a similar microangiopathy. Third, the elevated blood viscosity may combine with some circulation change unique to diabetes to generate microangiopathy. The proper choice between these three possibilities will depend on additional information.

\section{ACKNOWLEDGMENTS}

I am grateful to Ann Hegarty, Denise Overnell, Susan Dahlstrom, and Cheryl Garatoni for outstanding technical assistance.

This work was supported by Research Grant AM13092 from the National Institutes of Health, the Kroc Foundation, Santa Ynez, California, and the Doris Fay Palmer Fund.

\section{REFERENCES}

1. Cogan, D. G., L. Merola, and P. R. Laibson. 1961. Blood viscosity, serum hexosamine and diabetic retinopathy. Diabetes. 10: 393.

2. Skovborg, F., Aa. V. Nielsen, J. Schlichtkrull, and J. Ditzel. 1966. Blood-viscosity in diabetic patients. Lancet. $1: 129: 2: 805$.

3. Labib, M. A. M., A. M. Higazi, N. El-Ebrashy, S. El-Ashmawy, M. K. Madkour, and G. A. Barhooma. 1971. Studies on diabetic retinal vascular changes with special reference to blood coagulation and viscosity. Bull. Ophth. Soc. Egypt. 64: 457.

4. Hoare, E. M., A. G. Beckett, and J. Dormandy. 1973. Whole blood viscosity in diabetes. VIII Congress of the International Diabetes Federation, Brussels, Belgium, July 15-20, 1973. Abstracts. Excerpta Medica Foundation, Publishers, Amsterdam. 176.

5. Isogai, Y., K. Ichiba, A. Iida, I. Chikatsu, and M. Abe. 1971. Viscosity of blood and plasma in various diseases. In Theoretical and Clinical Hemorheology. H. H. Hartert and A. L. Copley, editors. SpringerVerlag KG., Berlin. 326.

6. Rees, S. B., L. Simon, G. A. Peltier, M. Balodimos, R. Gleason, A. Marble, and E. W. Merrill. 1967. Hemorheologic studies during the progression and remission of diabetic retinopathy. Biorheology. 4: 102. (Abstr.).

7. Zingg, W., J. C. Sulev, C. D. Morgan, and R. M. Ehrlich. 1971. Blood viscosity in diabetic children. Diabetologia. 7 : 461.

8. Bollinger, A., P. Berchtold, and W. Berger. 1969. Untersuchungen der Blutviskosität bei Diabetikern. Praxis. 58: 1104

9. Langer, L., S.-E. Bergentz, J. Bjure, and S.-E. Fagerberg. 1971. The effect of exercise on haematocrit, plasma volume and viscosity in diabetes mellitus. Diabetologia. $7: 29$.

10. Mosora, N., Tr. Baciu, and J. Vincze. 1972. The viscosity of the serum, hematocrit and fibrinogen in dia- 
betes mellitus and their relationship with diabetes mellitus. Diabetologia. 8: 59 (Abstr.).

11. Ditzel, J. 1968. Whole-blood viscosity and related components in diabetes mellitus. Dan. Med. Bull. 15: 49.

12. Hamwi, G. J. 1964. Therapy: Changing dietary concepts. In Diabetes Mellitus: Diagnosis and Treatment. Vol. 1. T. S. Danowski, editor. American Diabetes Association, New York. 74.

13. Wilkerson, H. L. C. 1964. Diagnosis : oral glucose tolerance tests. In Diabetes Mellitus: Diagnosis and Treatment. Vol. 1. T. S. Danowski, editor. American Diabetes Association, New York. 31.

14. Mirsky, I. A., P. Futterman, and R. H. Broh-Kahn. 1953. The quantitative measurement of vibratory perception in subjects with and without diabetes mellitus. J. Lab. Clin. Med. $41: 221$.

15. McMillan, D. E. 1972. Elevation of glycoprotein fucose in diabetes mellitus. Diabetes. 21: 863.

16. Wells, R. E. Jr., R. Denton, and E. W. Merrill. 1961. Measurement of viscosity of biologic fluids by cone plate viscometer. J. Lab. Clin. Med. 57: 646.

17. Kragh, A. M. 1961. Viscosity. Anal. Methods Protein Chem. 3: 173 .

18. Gornall, A. G., C. J. Bardawill, and M. M. David. 1949. Determination of serum proteins by means of the biuret reactions. J. Biol. Chem. 177: 751 .

19. Yang, J. T. 1961. The viscosity of macromolecules in relation to molecular conformation. Adv. Protein Chem. $16: 323$.

20. Van Slyke, D. D., A. Hiller, R. A. Phillips, P. B. Hamilton, V. P. Dole, R. M. Archibald, and H. A. Eder. 1950. The estimation of plasma protein concentration from plasma specific gravity. J. Biol. Chem. $183: 331$.

21. Oncley, J. L., G. Scatchard, and A. Brown. 1947. Physical-chemical characteristics of certain of the proteins of normal human plasma. J. Phys. Colloid Chem. 51: 184.

22. Snedecor, G. W., and W. G. Cochran. 1967. Statistical Methods. Iowa State University Press, Ames, Iowa. 6th edition. 135, 173, 277, 285, 438, 484.

23. Cannon, M. R., R. E. Manning, and J. D. Bell. 1960. Viscosity measurement. The kinetic energy correction and a new viscometer. Anal. Chem. 32: 355.
24. Stokes, R. H., and R. Mills. 1965. Viscosity of Electrolytes and Related Properties. Pergamon Press Ltd., Oxford. 118.

25. Lowry, O. H., N. J. Rosebrough, A. L. Farr, and R. J. Randall. 1951. Protein measurement with the Folin phenol reagent. J. Biol. Chem. 193: 265.

26. Lange, H. F. 1946. The normal plasma protein values and their relative variations. Acta Med. Scand. Suppl. $176: 1$.

27. McMillan, D. E. 1970. Changes in serum proteins and protein-bound carbohydrates in diabetes mellitus. Diabetologia. 6 : 597.

28. Einstein, A. 1926. Investigations on the Theory of the Brownian Movement. R. Furth, editor. Methuen \& Co. Ltd., London. 54.

29. Vand, V. 1948. Viscosity of solutions and suspensions. II. Experimental determination of the viscosity-concentration function of spherical suspensions. J. Phys. Colloid Chem. 52: 300.

30. Owen, J. A. 1967. Effect of injury on plasma proteins. Adv. Clin. Chem. 9: 1.

31. Wiedermann, D., D. Wiedermannova, and K. Cidl. 1966. On the dynamics of haptoglobin and other acute phase reactant levels during Scarlet Fever and convalescence. Protides Biol. Fluids Proc. Colloq. Bruges. $14: 385$.

32. Tanford, C., and J. G. Buzzell. 1965. The viscosity of aqueous solutions of bovine serum albumin between pH 4.3 and 10.5. J. Phys. Chem. 60: 225.

33. Hess, E. L., and A. Cobure. 1949. The intrinsic viscosity of mixed protein systems, including studies of plasma and serum. J. Gen. Physiol. 33: 511.

34. Schultze, H. E., and J. F. Heremans. 1966. Molecular Biology of Human Proteins. Vol. 1, Nature and Metabolism of Extracellular Proteins. Elsevier, N. V. Uitgevers Mij., Amsterdam. 177 and 179.

35. MacKenzie, M. R., H. H. Fudenberg, and R. A. O'Reilly. 1970. The hyperviscosity syndrome. I. In IgG myeloma. The role of protein concentration and molecular shape. J. Clin. Invest. 49: 15.

36. Steel, A. E. 1959. The viscosity of macroglobulin and euglobulin solutions. Clin. Chim. Acta. 4: 503.

37. Fahey, J. L. 1963. Serum protein disorders causing clinical symptoms in malignant neoplastic disease. $J$. Chronic Dis. 16: 703. 